\title{
Wybrane oprawy ksiąg kanonika gnieźnieńskiego Stanisława Grota (zm. 1624)
}

\begin{abstract}
Streszczenie. Niniejszy artykuł kładzie nacisk na problematykę opraw ksiąg, które znalazły się w kolekcji kanonika gnieźnieńskiego Stanisława Grota. Rozpoznany do tej pory fragment księgozbioru duchownego liczy 45 druków. Wszystkie omówione woluminy należą do zasobu Archiwum Archidiecezjalnego w Gnieźnie. Największą część biblioteki kanonika stanowią druki traktujące o prawie kanonicznym, świeckim oraz kazania. Oprawy tych druków w większości zostały wykonane z desek bądź tektury oraz jasnej skóry dodatkowo pokrytej dekoracjami. Z pewnością przeważają oprawy w typie niemieckiego renesansu o kompozycji ramowej. Sporą część tworzą również oprawy o wymowie kontrreformacyjnej, ozdobione plakietami z monogramem IHS. Jak wynika z badań nad znakami wodnymi, kanonik zaopatrywał się nie tylko u lokalnych introligatorów, ale też m.in. u rzemieślników z Małopolski.
\end{abstract}

Słowa kluczowe: oprawy, kanonik Stanisław Grot, introligator Wilhelm, biblioteka katedralna, stare druki.

Jeden z księgozbiorów, jakie udało się wyodrębnić z zasobu biblioteki katedralnej w Gnieźnie ${ }^{1}$, należał pierwotnie do kanonika gnieźnieńskiego Stanisława Grota (zm. 1624). Nim został on kanonikiem, pełnił urząd notariusza publicznego ${ }^{2}$, był również plebanem magierowskim³ ${ }^{3}$.

1 Prace prowadzone w ramach projektów: „Inwentaryzacja zasobu Biblioteki Katedralnej w Gnieźnie” oraz „Inwentaryzacja zasobu Archiwum Archidiecezjalnego w Gnieźnie: starodruki z Kolekcji Seminaryjnej Biblioteki Katedralnej i nowoodnalezione dokumenty papierowe konsystorza gnieźnieńskiego z XV i pocz. XVI w." pod kierunkiem prof. UAM dr. hab. Piotra Pokory.

2 H. Gmiterek, Album studentów Akademii Zamojskiej 1595-1781, Warszawa 1994, s. 64 .

3 Archiwum Archidiecezjalne w Gnieźnie [dalej: AAG], sygn. ACap. B 70, k. $810 \mathrm{v}$. 
Kształcił się m.in. w Rzymie, gdzie zdobył doktoraty z teologii oraz obojga praw ${ }^{4}$. W Gnieźnie pierwszy raz pojawił się, jako pełnomocnik Wawrzyńca Gembickiego ${ }^{5}$, podczas obejmowania przez niego arcybiskupstwa. W 1616 roku objął kanonię po zmarłym kanoniku Tomaszu Josickim ${ }^{6}$. Pełnił przez rok funkcję bibliotekarza gnieźnieńskiej kapituły, którego zadaniem było uporządkowanie oraz opisanie zgromadzonego księgozbioru. Zmarł po wybuchu epidemii tzw. morowego powietrza w 1624 roku.

Na podstawie zamieszczonych w woluminach proweniencji pośmiertnych rozpoznany obecnie fragment księgozbioru kanonika liczy 45 druków. Niewątpliwie dalsze prace inwentaryzacyjne w zasobie biblioteki katedralnej pozwolą na odnalezienie kolejnych woluminów ze zbioru kanonika Stanisława Grota7. Najobszerniejszą część księgozbioru tworzą druki traktujące o prawie kanonicznym, cywilnym oraz kazania, co znajduje uzasadnienie $\mathrm{w}$ wykształceniu duchownego. Nie brakuje w nim również dzieł z zakresu patrologii, apologetyki, filozofii czy poezji ${ }^{8}$. W niniejszym artykule główny nacisk położony zostanie jednak na problematykę opraw ksiąg znajdujących się w kolekcji kanonika. W tym niewielkim księgozbiorze większość opraw wykonano z desek bądź tektury oraz jasnej skóry dodatkowo pokrytej dekoracjami.

Najstarsze oprawy zachowane w opisywanym księgozbiorze tworzą grupę składającą się z trzech egzemplarzy. Górna okładzina pierwszego woluminu ${ }^{9}$ została ozdobiona złoconym wyciskiem radełka $\mathrm{z}$ ornamentem plecionkowym, tworzącym zewnętrzną ramę. W górnej strefie zamieszczono napis: „RETHORICA AD HARENN”, natomiast w dolnej wyciśnięto datę wykonania oprawy: „[15]36”. Zwierciadło wypełniono nieczytelnym już wyciskiem prostokątnej plakiety z wyobrażeniem

4 AAG, sygn. ACap B 70, k. 812v.-817r.

5 J. Korytkowski, Prymasowie i metropolici polscy od roku 1000 aż do roku 1821, Poznań 1889 , t. 3, s. 636.

6 Zob. M. Muraszko, Wybrane oprawy ksiag z prywatnych bibliotek polskich w zbiorach kanonika gnieźnieńskiego Tomasza Josickiego, „Studia Europaea Gnesnensia” 2015, t. 12, s. 261-274 (tam zebrana starsza literatura).

7 W trakcie powstawania niniejszego artykułu udało się zidentyfikować dwa kolejne woluminy z badanego księgozbioru Grota.

8 Wśród nich m.in. dzieła autorstwa: Cycerona (Rhetoricorum, Coloniae: Ioannes Gymnicus, 1535 - AAG, sygn. BK 444), św. Hieronima ze Strydonu (Opervm, Tomvs V, Coloniae Agrippinae: Antonij Hierat, 1616 - AAG, sygn. BK 3135) oraz Erazma z Rotterdamu (Civilitas Morum, Cracoviae: In Officina Hieronymi Scharffenebrgi, 1548 AAG, sygn. BK 1131 adl.).

9 AAG, sygn. BK 444. Pierwszy omawiany wolumin został poddany dawnej konserwacji, w wyniku której zachowano jedynie oryginalne obleczenie. 
postaci, najpewniej świętego. W narożnikach umieszczono wyciski tłoka z motywem żołędzia. Dekoracja okładziny dolnej, ze względu na liczne pęknięcia skóry, jest mało czytelna. Widoczny jest zarys postaci wkomponowanej pod łukiem renesansowej arkady.

Kolejna, młodsza oprawa (il. 1) wykonana jest z fazowanych desek bukowych oraz ciemnej skóry ${ }^{10}$. W przypadku górnej okładziny jej dekorację oparto na kompozycji ramowej, utworzonej za pomocą strychulca oraz wycisków radełek. Zewnętrzną ramę tworzą ślepe wyciski radełka $\mathrm{z}$ ornamentem palmetowo-arkadkowym. W prostokątnych polach, utworzonych za pomocą strychulca, w górnej strefie, umieszczono wyciski liternicze: „INSTITVTIONES TEOLOI” (sic!), odnoszące się do zawartości treściowej druku. Wycisk radełka tworzącego wewnętrzną ramę przedstawia półpostaci: Chrystusa, Dawida, św. Pawła oraz Jana Ewangelisty ${ }^{11}$. W zwierciadle umieszczono kolejną ramę, którą tworzy wycisk radełka $\mathrm{z}$ medalionami o obramieniu $\mathrm{w}$ formie stylizowanego wieńca laurowego, w których ukazane są profilowe popiersia antycznych wojowników. Powierzchnię między medalionami zdobi ornament kandelabrowo-roślinny. Centrum zwierciadła dopełnia pionowy wycisk radełka z ornamentem palmetowo-arkadkowym. Dekoracja okładziny dolnej została oparta na tych samych założeniach kompozycyjnych oraz wytworzona z wykorzystaniem tych samych narzędzi. Wykonanie oprawy przypisać można działającemu w Poznaniu introligatorowi MC lub też Melchiorowi Neringowi (zm. 1587) ${ }^{12}$. Na poznańskie pochodzenie obiektu wskazuje

10 AAG, sygn. BK 806.

${ }^{11}$ Szczegółowy opis dekoracji tego radełka podaje M. Czapnik, Oprawy poznańskiego monogramisty MC, w: Tegumentologia Polska dzisiaj, red. A. Wagner, Torun 2015, s. 141.

12 Zob. M. Czapnik, op.cit., s. 135; A. Wagner, Oprawy ksiag Andrzeja Opalińskiego, w: Księgozbiór wielkopolskiego magnata. Andrzej Opalinski (1540-1593), red. A. Wagner, Poznań 2011, s. 155-161 oraz il. na s. 154; por. Biblioteka Poznańskiego Towarzystwa Przyjaciół Nauk [dalej: Biblioteka PTPN], sygn. 8128. I, zob. Baza Opraw Zabytkowych XV-XVIII w., red. A. Wagner, https://ptpn.locloud.pl/items/show/4711 [dostęp: 15.03.2019]; Drukarze dawnej Polski od XV do XVIII wieku, t. 4, Pomorze, oprac. A. Kawecka-Gryczowa, K. Korotajowa, Wrocław 1962, s. 272-291; J. Sójka, Nering Melchior, w: Wielkopolski słownik biograficzny, red. A. Gąsiorowski, J. Topolski, Warszawa-Poznań 1981, s. 509; M. Muraszko, Neringowskie oprawy trzech druków z księgozbioru opata trzemeszeńskiego Wojciecha Mielińskiego, „Biuletyn Biblioteki Jagiellońskiej” 2017, t. 67, s. 211-220. Radełko all'antica występujące na oprawie BK 806 według badań Marianny Czapnik należało do introligatora o inicjałach MC, który działał w Poznaniu do 1564 roku. Wynikałoby z tego, iż oprawa będąca własnością kanonika Stanisława Grota została wykonana przez tegoż właśnie mistrza. Jednak oprawy sporządzone w podobnym czasie oraz udekorowane wspomnianym radełkiem Arkadiusz 
również, znajdujący się na wyklejce, filigran z herbem Poznania ${ }^{13}$. Ostatnia $\mathrm{z}$ opraw zaliczanych do najstarszych $\mathrm{w}$ księgozbiorze chroni druk wydany w 1518 roku w Argen autorstwa Jana Vallensisa ${ }^{14}$. Wykonano ją $\mathrm{z}$ fazowanych desek obciągniętych ciemną skórą. $\mathrm{W}$ tym przypadku częściowo zachowały się także jej mosiężne zapięcia. Dekoracja obu okładzin jest analogiczna. Zewnętrzną ramę tworzy ślepy wycisk radełka oznaczonego monogramem WC i datą 1534 roku oraz przedstawiającego Karola Habsburga ${ }^{15}$. Za pomocą strychulca wyciśnięto linie tworzące wewnętrzną ramę, w której narożnikach umieszczono wyciski z motywem trójlistka, wzbogacone małymi rozetkami. W górnej oraz dolnej strefie okładziny wkomponowano wyciski liternicze: „SVMA IOA NIS WALLE", odnoszące się do tytułu oraz autora dzieła. Zwierciadło utworzono za pomocą wycisku radełka z wyobrażeniem Lukrecji oraz personifikacjami cnót Męstwa i Sprawiedliwości. Znak wodny znajdujący się na wyklejce przedstawia herb Bonarowa, co łączy się w literaturze z papiernią w Balicach ${ }^{16}$. Wskazuje to na małopolskie pochodzenie oprawy.

W zbiorze Grota znajdują się cztery woluminy otrzymane od znajomego kanonika Stanisława Karśnickiego ${ }^{17}$. Oprawy te chronią dzieła Justyniana Wielkiego, wydane w 1551 roku w Lyonie. Inicjatorem oprawienia druków i najprawdopodobniej pierwszym ich właścicielem był niezidentyfikowany Doliwita, którego superekslibris introligatorski ${ }^{18}$ znajduje się na wszystkich czterech oprawach. Ich okładziny (il. 2) zostały wykonane z tektur obleczonych ciemną skórą. Na każdym egzemplarzu występuje również analogiczna dekoracja okładziny górnej: zewnętrzna rama została utworzona za pomocą ślepego wycisku radełka z personifikacjami czterech

Wagner przypisuje do warsztatu Melchiora Neringa, działającego w Poznaniu od 1559 roku. Wydaje się, że kwestia atrybucji opraw powstałych między 1559 a 1564 rokiem wymaga dalszych szczegółowych badań. Być może pozwolą one na bardziej jednoznaczne ich powiązanie z którymś ze wspomnianych warsztatów introligatorskich. Problematyce tej poświęcony będzie m.in. fragment przygotowywanej przeze mnie pracy magisterskiej poświęconej warsztatowi introligatorskiemu Melchiora Neringa. Zdaję sobie sprawę, że problem jest skomplikowany i wymaga szerszych badań.

${ }^{13}$ J. Siniarska-Czaplicka, Filigrany papierni położonych na obszarze Rzeczypospolitej Polskiej od poczatku XVI do połowy XVIII wieku, Wrocław 1969, s. 17-18.

14 AAG, sygn. BK 1031.

${ }^{15}$ Więcej na temat tego narzędzia pisze M. Jarosławiecka-Gąsiorowska, Ikonografia świecka na oprawach XVI i XVII w., „Rocznik Biblioteki Narodowej” 1970, s. 330.

${ }^{16}$ J. Siniarska-Czaplicka, op.cit., s. 7.

17 AAG, sygn. BK 752, BK 753, BK 771, BK 1203.

${ }^{18} \mathrm{O}$ tej kategorii superekslibrisów m.in. w: M. Sipayłł, Polskie superexlibrisy XVI-XVIII wieku w zbiorach Biblioteki Uniwersyteckiej w Warszawie, Warszawa 1988, s. 6. 


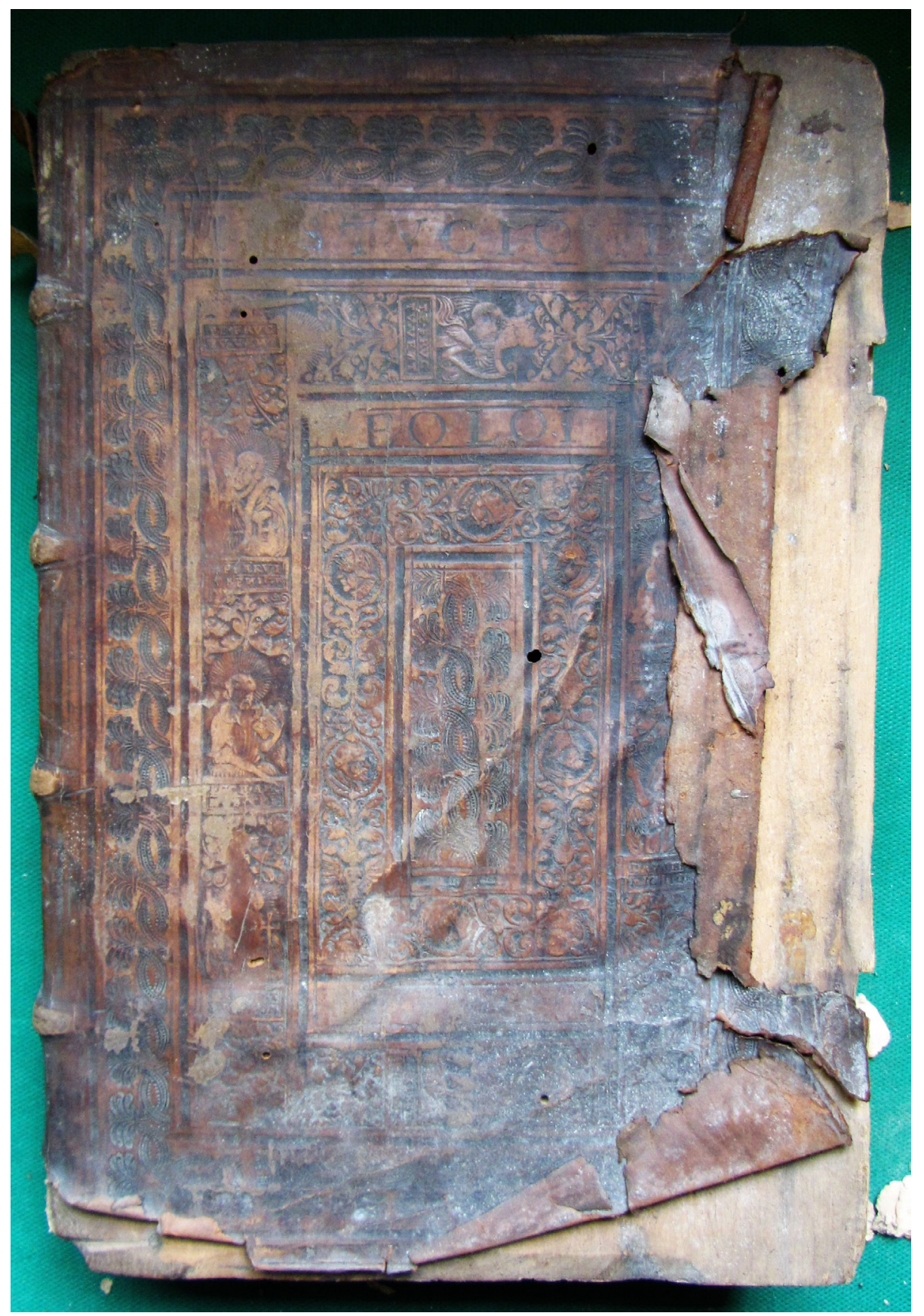

Il. 1. Oprawa druku z 1558 roku (górna okładzina), introligator MC lub Melchior Nering

Źródło: Archiwum Archidiecezjalne w Gnieźnie, fot. Aleksandra Wajnert. 


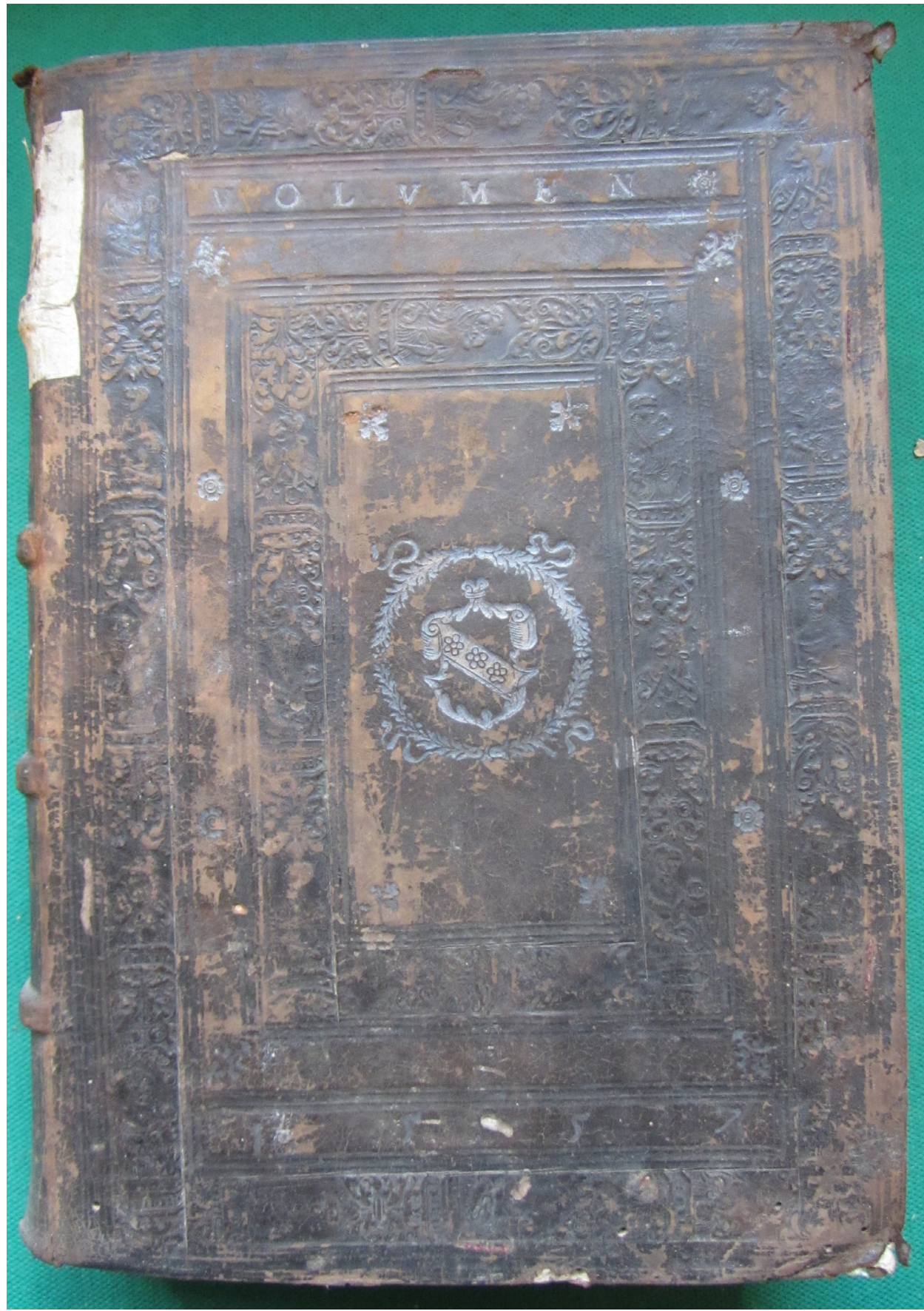

Il. 2. Oprawa druku z 1551 roku (górna okładzina), introligator krakowski (?) Źródło: Archiwum Archidiecezjalne w Gnieźnie, fot. Aleksandra Wajnert. 
cnót: Nadzieją (SPES), Wiarą (FIDES), Sprawiedliwością (IVSTICIA) oraz Miłością (CARITAS), które oddzielono ornamentem arabeskowym. Narożniki ozdobiono wyciskami tłoka z motywem floralnym, a całość uzupełniono wyciskami małych, złoconych rozetek. W listwach w górnej oraz dolnej strefie każdej z górnych okładzin zamieszczone zostały wyciski liternicze z tytułami dzieł („DIGESTVM NOVVM", „DIGESTVM VETVS”, "CODEX”, „VOLVMEN”) oraz datą: „1557”, wskazującą czas oprawienia druków. Wewnętrzna rama wyznaczająca granice zwierciadła została wykonana za pomocą wyżej wspomnianego radełka z przedstawieniem cnót. Centrum zwierciadła zajmuje złocony superekslibris przedstawiający tarczę z godłem herbu Doliwa w roślinnym wieńcu laurowym z czterema wstęgami ${ }^{19}$. W wewnętrznych narożnikach zwierciadła znajdują się złocone tzw. szlaggoldem wyciski floralnych tłoków. Okładziny dolne ozdobiono strychulcem, tłokami z motywami floralnymi oraz wspomnianym wyżej radełkiem z personifikacjami cnót. Wykonanie tych opraw należałoby łączyć z krakowskim introligatorstwem, na co wskazuje filigran $\mathrm{z}$ herbem Bonarowa ${ }^{20}$, przypisywany przez historyków papiernictwa do młyna w Balicach pod Krakowem.

Kolejną wyodrębnioną grupę tworzą oprawy chroniące dzieła św. Ambrożego ${ }^{21}$. Wykonane $\mathrm{z}$ fazowanych desek bukowych, obciągnięte jasną skóra, w jednym egzemplarzu z zachowanymi zapięciami mosiężno-skórzanymi. Dekoracje ich okładzin oparto na kompozycji ramowej i wykonano je metodą ślepego wycisku, zaczynając od zewnątrz od ornamentu palmetowo-arkadkowego. Następnie strychulcem wykonano cztery poziome listwy, po dwie $\mathrm{w}$ górnej oraz dolnej strefie okładziny. W powstałych $\mathrm{w}$ ten sposób polach wyciśnięto na złoto tytuły oraz numery tomów oprawionych dzieł: "S AMBROSII OPEVRVM TOMVS PRIMVS SECVND TERTIVS" oraz "S AMBROSII OPEVRVM TOMVS IV V ET INDEX". Kolejną ramę udekorowano wyciskami radełek z przedstawieniem trzech półpostaci kobiecych (Wenus, Chloe i Lukrecja), dodatkowo rozdzielonymi medalionami popiersiowymi oraz ornamentem floralnym. Zwierciadło zdobi wycisk prostokątnej plakiety ze sceną Ukrzyżowania $^{22}$. Dolną okładzinę udekorowano identycznie. Być może oprawy te są dziełem wielkopolskiego warsztatu introligatorskiego, na co wskazuje

${ }^{19}$ A. Wagner, Superekslibris polski. Studium o kulturze bibliofilskiej i sztuce od średniowiecza do połowy XVII wieku, Toruń 2016, s. 215-219.

${ }^{20}$ J. Siniarska-Czaplicka, op.cit., s. 7.

${ }^{21}$ AAG, sygn. BK 3214, BK 3235.

${ }^{22}$ Wyciski zbliżonych plakiet zob. EBDB p001527; p003638; p000391. Einbanddatenbank, https://www.hist-einband.de [dostęp: 23.06.2018]. 
filigran z herbem Łodzia (dodatkowo ozdobiony insygniami godności biskupiej). Oznaczony w ten sposób papier łączy się z młynem biskupów poznańskich, znajdującym się we wsi Główna ${ }^{23}$.

Grot w swojej kolekcji posiadał druki oprawione przez krakowskiego introligatora Wilhelma. Są to trzy egzemplarze: dwa zawierające dzieła Filipa Bosquiera ${ }^{24}$ oraz jedno pióra Juana Lopeza ${ }^{25}$. Okładziny dwóch z nich wykonane są z desek, trzecia natomiast $\mathrm{z}$ tektury. Wszystkie obleczono jasną skórą. Do dekoracji opraw dzieł Bosquiera introligator posłużył się sygnowanym radełkiem z przedstawieniem Ewangelistów (il. 3a) z atrybutami: św. Łukasza, św. Marka, św. Mateusza oraz św. Jana (przy postaci św. Mateusza widoczny jest monogram "G", natomiast przy św. Łukaszu występuje „L"), radełkiem ze scenami z Nowego Testamentu (il. 3b): kuszenie Adama i Ewy, Zmartwychwstanie, Ukrzyżowanie, wywyższenie Węża Miedzianego oraz radełkiem z ornamentem floralnym, w który został wpleciony monogram "G" (il. 3c). W zwierciadłach wyciśnięto złoconą owalną plakietę $e^{26}$ na papierowej podkładce z przedstawieniem Baranka Paschalnego. Wspomniane wyżej sygle "G" oraz „L" w przypadku jednego i drugiego radełka mogą odnosić się do łacińskiej wersji imienia Wilhelm, czyli Guilelmus, niewykluczone jednak, że są to inicjały rzemieślnika, któremu zlecono wykonanie przedstawionych narzędzi ${ }^{27}$. Na wyklejkach obu woluminów znajdują się filigrany z wyobrażeniem herbu Duchaków, co wskazuje na małopolską papiernię w Prądniku Czerwonym, zwanym Wielkim²8. Górną okładzinę trzeciej oprawy zdobią wyciski tzw. radełka jagiellońskiego z portretami: Zygmunta Starego, Bony, Zygmunta Augusta oraz Katarzyny ${ }^{29}$. Zwierciadło, jak wyżej, zdobi wycisk plakiety z przedstawieniem Baranka Paschalnego, lecz odciśniętej za pomocą innego tłoka. Dolna okładzina w całości została zapełniona wyciskiem wspomnianego już radełka jagiellońskiego.

W zbiorze kanonika znajdują się również trzy oprawy, do których dekoracji użyto analogicznych rozwiązań kompozycyjnych. Wszystkie woluminy wykonano z bukowych, fazowanych desek, na które naciągnięto

${ }^{23}$ J. Siniarska-Czaplicka, op.cit., s. 14.

24 AAG, sygn. BK 5084, BK 3146.

25 AAG, sygn. BK 8228.

${ }^{26}$ A. Wagner, Superekslibris polski..., s. 471-472.

${ }^{27}$ Jak dotąd nieodnotowane w literaturze.

${ }^{28}$ J. Siniarska-Czaplicka, op.cit., s. 8.

${ }^{29}$ A. Lewicka-Kamińska, Rzut oka na rozwój oprawy książkowej w Krakowie, "Rocznik Biblioteki Narodowej" 1973, s. 56; M. Jarosławiecka-Gąsiorowska, op.cit., s. 333. 


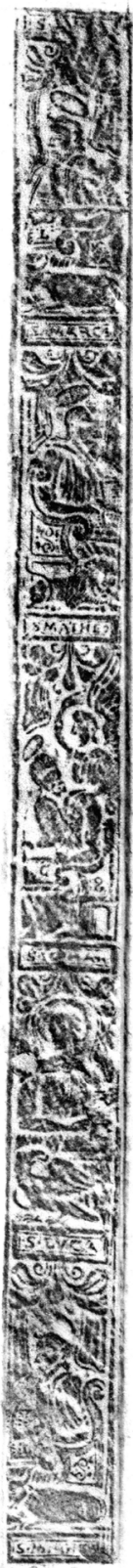

a

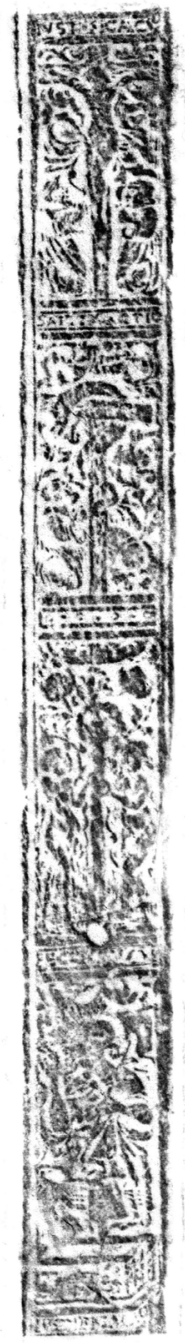

b

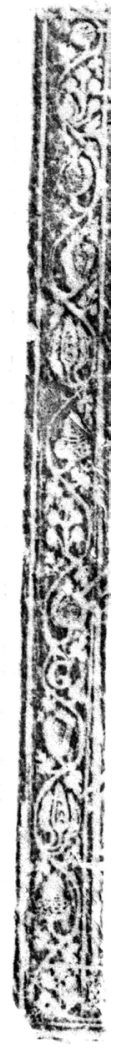

c

Il. 3 a-c. Przerysy ołówkowe wycisków radełek na oprawie starodruku z 1620 roku (górna okładzina), introligator Wilhelm Źródło: Archiwum Archidiecezjalne w Gnieźnie, fot. Aleksandra Wajnert. 


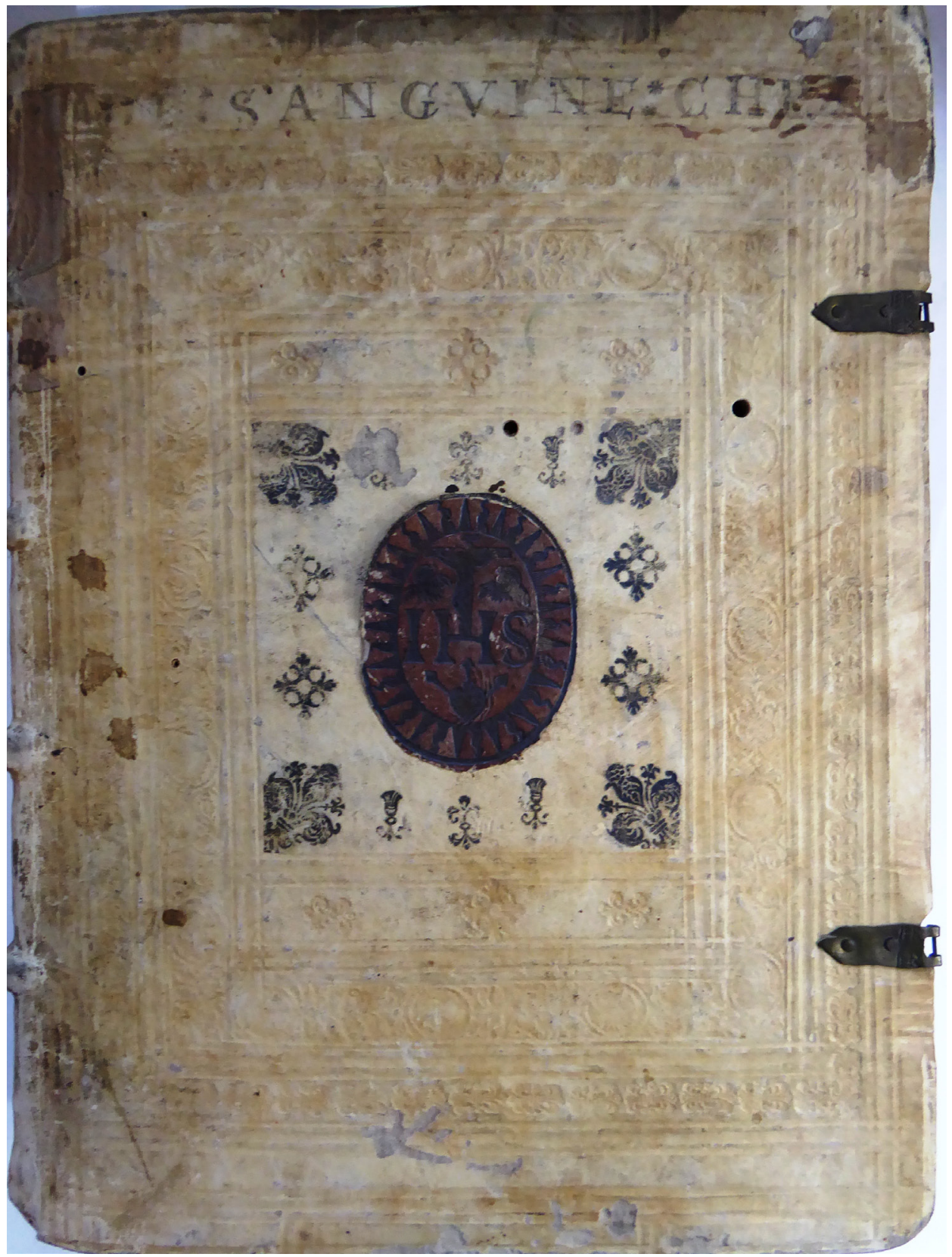

Il. 4. Wycisk plakiety z monogramem IHS w otoczeniu motywów floralnych na oprawie starodruku z 1617 roku (górna okładzina)

Źródło: Archiwum Archidiecezjalne w Gnieźnie, fot. Aleksandra Wajnert. 
białą świńską skórę. Górną okładzinę pierwszej z opraw ${ }^{30}$ od zewnątrz zdobią wyciski radełka $\mathrm{z}$ ornamentem floralnym, następnie palmetowo-arkadkowym. Trzecia, wewnętrzna rama przedstawia medalionowe popiersia oddzielone ornamentem arabeskowym. W centrum zwierciadła umieszczony został wycisk plakiety z monogramem IHS w romboidalnym obramieniu wypełnionym ornamentem roślinnym $\mathrm{z}$ elementami arabeski $^{31}$. Dekorację dolnej okładziny opracowano w niemal analogiczny sposób, z wyjątkiem zwierciadła, które zostało pozbawione dekoracji. Kolejne dwie oprawy ${ }^{32}$, nieco uboższe dekoracyjnie, ozdobiono wyciskami różnych radełek $\mathrm{z}$ popiersiami $\mathrm{w}$ medalionach. W zwierciadłach znajdują się owalne wyciski plakiet z monogramem IHS w obecności główek anielskich i serc z gwoździami (il. 4). Wyciski plakiet pierwotnie zostały umieszczone na czerwonych, papierowych podkładkach. Całość dopełniają wyciski łłoków floralnych. Dolne okładziny wykonano analogicznie, z tym że zwierciadła wypełniono tłokami floralnymi oraz medalionowym radełkiem.

Oprawy chroniące druki należące pierwotnie do gnieźnieńskiego kanonika w zdecydowanej większości zostały wykonane z bukowych, fazowanych desek obleczonych białą świńską skórą. Udekorowano je za pomocą strychulców, radełek wyciskanych na ślepo oraz owalnych plakiet na papierowych podkładkach (z przedstawieniem Baranka Paschalnego, z monogramem IHS). Warto zauważyć, że tendencja ta uwidocznia się po objęciu przez Grota kanonii w 1616 roku. Wśród zebranych woluminów wyróżnić można również oprawy nawiązujące do dekoracji w typie niemieckiego renesansu. Niektóre z egzemplarzy dzięki umieszczeniu na ich okładzinach wycisków plakiet z Barankiem Paschalnym czy monogramem IHS zyskały wymowę kontrreformacyjną. Analiza znaków wodnych wykorzystanych do sporządzenia wyklejek woluminów wskazuje, że Stanisław, będąc już kanonikiem gnieźnieńskim, zaopatrywał się w druki oprawione nie tylko u lokalnych introligatorów, lecz także u tych działających w Małopolsce.

30 AAG, sygn. BK 2887.

${ }^{31}$ Plakieta pierwotnie odciśnięta została na papierowej podkładce, która nie zachowała się do dzisiejszych czasów.

${ }^{32}$ AAG, sygn. BK 5659, BK 5752. 


\section{Bibliografia}

Czapnik M., Oprawy poznańskiego monogramisty MC, w: Tegumentologia Polska dzisiaj, red. A. Wagner, Toruń: Wydawnictwo Naukowe Uniwersytetu Mikołaja Kopernika 2015.

Drukarze dawnej Polski od XV do XVIII wieku, t. 4, Pomorze, oprac. A. Kawecka-Gryczowa, K. Korotajowa, Wrocław: Zakład Narodowy im. Ossolińskich Wydawnictwo PAN 1962.

Gmiterek H., Album studentów Akademii Zamojskiej 1595-1781, Warszawa: Instytut Historii Nauki PAN, Zakład Dziejów Oświaty 1994.

Jarosławiecka-Gąsiorowska M., Ikonografia świecka na oprawach XVI i XVII w., „Rocznik Biblioteki Narodowej” 1970, s. 315-337.

Korytkowski J., Prymasowie i metropolici polscy od roku 1000 aż do roku 1821, Poznań: Nakładem Kuryera Poznańskiego 1889, t. 3.

Lewicka-Kamińska A., Rzut oka na rozwój oprawy książowej w Krakowie, „Rocznik Biblioteki Narodowej" 1973.

Muraszko M., Neringowskie oprawy trzech druków z księgozbioru opata trzemeszeńskiego Wojciecha Mielińskiego, „Biuletyn Biblioteki Jagiellońskiej” 2017, t. 67.

Muraszko M., Wybrane oprawy ksiag z prywatnych bibliotek polskich w zbiorach kanonika gnieźnieńskiego Tomasza Josickiego, „Studia Europaea Gnesnensia” 2015, t. 12.

Siniarska-Czaplicka J., Filigrany papierni położonych na obszarze Rzeczypospolitej Polskiej od poczatku XVI do połowy XVIII wieku, Wrocław: Zakład Narodowy im. Ossolińskich - Wydawnictwo PAN 1969.

Sipayłło M., Polskie superexlibrisy XVI-XVIII wieku w zbiorach Biblioteki Uniwersyteckiej w Warszawie, Warszawa: Instytut Wydawniczy PAX 1988.

Sójka J., Nering Melchior, w: Wielkopolski słownik biograficzny, red. A. Gąsiorowski, J. Topolski, Warszawa-Poznań: Państwowe Wydawnictwo Naukowe 1981.

Wagner A., Oprawy ksiag Andrzeja Opalińskiego, w: Księgozbiór wielkopolskiego magnata. Andrzej Opaliński (1540-1593), red. A. Wagner, Poznań: PTPN 2011.

Wagner A., Superekslibris polski. Studium o kulturze bibliofilskiej i sztuce od średniowiecza do połowy XVII wieku, Toruń: Wydawnictwo Naukowe Uniwersytetu Mikołaja Kopernika 2016.

Wagner A., Wolumin z księgozbioru Mikołaja Korycińskiego z rękopiśmiennym fragmentem tekstu Filipa Melanchtona, „Odrodzenie i Reformacja w Polsce” 2014, t. 58 . 


\title{
ALEKSANDRA WAJNERT \\ Selected book bindings from the collection of the Gniezno canon Stanisław Grot (d. 1624)
}

\begin{abstract}
This article focuses on the issues concerning the bindings of books that formed the book collection of the Gniezno canon Stanisław Grot. The identified section of the collection that belonged to Grot amounts to forty five old prints. All volumes discussed in the article come from the Archdiocesan Archives in Gniezno. The bulk of the canon's library comprises books on canon and secular law and on sermons. The bindings of these old prints are predominantly made of planks or cardboard and light vellum (hide) that had been additionally embellished with ornamentation. Undoubtedly, the bindings made according to the traditional craft of German Renaissance bookbinding and with a framework composition are in preponderance. A sizeable number of bindings feature clearly Counter-Reformation setting with religious symbolism that is clearly Counter Reformation in purpose and with the monograph IHS. As it has been revealed from the analysis of the watermarks, the canon used the binding services of not only local book binders, but also those from the Lesser Poland region.
\end{abstract}

Keywords: bindings; canon Stanisław Grot; Wilhelm; master book binder; cathedral library; old prints.

Tekst wpłynął do Redakcji 29 maja 2019 roku. 
